\title{
Place quality in high-speed rail station areas: Concept definition
}

\author{
Jinglun Du \\ Eindhoven University of Technology \\ j.du1@tue.nl
}

\author{
Pieter van Wesemael \\ Eindhoven University of Technology \\ p.j.v.v.wesemael@tue.nl
}

\author{
Oana Druta \\ Eindhoven University of Technology \\ o.druta@tue.nl
}

\begin{abstract}
High-speed railway (HSR) station areas are expected to benefit urban environments, not simply as transportation or economic hubs but also as urban places contributing to living quality. However, the relationship between HSR and place quality has not received systematic attention, despite the evolution of urban planning paradigms toward a clearer focus on quality of life. We have reviewed 44 academic articles written between 1996 and 2019 and analyzed concepts of place quality spanning the disciplines of urban design, urban planning, and urban economics. We identified three dimensions commonly associated with quality of place: a spatial dimension associated with aesthetic qualities of urban spaces; a socio-cultural dimension associated with experienced "sense of place"; and an economic dimension associated with the agglomeration of economic activities. Then we worked out these three dimensions in the context of HSR station areas and attributed features accordingly. We concluded that the economic dimension far outweighs the others in academic debates, with dominant theories being primarily concerned with land use, accessibility, and economic performance. Studies from the urban design field have tackled the spatial elements of place quality and showed a strong correlation with economic dimension. However, the literature remains insufficiently developed when it comes to addressing user experience and "sense of place."
\end{abstract}

\section{Article history:}

Received: June 9, 2020

Received in revised form: June 14, 2021

Accepted: August 8, 2021

Available online: October 27, 2021

\section{Introduction}

Urban planning increasingly treats transportation hubs as hybrid systems combining transit, economic and socio-cultural urban activities (Conticelli \& Tondelli, 2013; Stevens, 2015). High-speed rail (HSR) area developments are costly, high-stakes urban projects, with complex expectations riding on them, such as improving inter-urban and international connectivity, generating investment and economic activity, and increasing the competitiveness of urban areas. In Europe, for example, HSR station developments are expected to play a significant role in urban renaissance of the historical city core (Bertolini, 1998; 2000), as well as fulfilling railway transit role. Meanwhile, in Asia, fast-paced metropolitan expansion is planned in parallel with the HSR network development, and the construction of large scale HSR stations provides one of the key factors enabling new town growth. Place quality as a feature

Copyright 2021 Jinglun Du, Oana Druta \& Pieter van Wesemael

http://dx.doi.org/10.5198/jtlu.2021.1820

ISSN: 1938-7849 | Licensed under the Creative Commons Attribution - Noncommercial License 4.0

The Journal of Transport and Land Use is the official journal of the World Society for Transport and Land Use (WSTLUR) and is published and sponsored by the University of Minnesota Center for Transportation Studies. 
enhancing the ability of station areas to support active social and cultural urban life, and better quality of life for urbanites, has only over the last two decades become a component of transit oriented developments (TOD), including HSR developments (Beckerich et al., 2017; Balducci \& Bertolini, 2007; Van Den Berg \& Pol, 1998; Vreeker, 2008)

Despite the growing importance of place quality in the planning of station areas, many researchers claim that a) the place quality of newly developed HSR station areas usually fail to satisfy passengers and citizens (Dai, 2018; Wang, 2014), b) our understanding of the concept of place quality and its features is insufficiently developed (Dai 2018; Mota \& López, 2014; Peters, 2009; Peters \& Novy, 2012; Du et al., 2021), and c) the development of appropriate, comprehensive tools for evaluating the quality of place in HSR station areas are lacking (Yin, Bertolini, \& Duan, 2015). Dominant urban planning concepts and strategies like CBD or TOD narrow our understanding and planning practices to transit, land use and economic dimensions, while at most hinting to the need for more inclusive and holistic concepts and strategies defining HSR station areas as an important hub in the social tissue of urban places. Finally, the first attempts towards conceptualisation of place quality in HSR station areas stem from specific disciplinary interpretations of place quality, and either talk passed each other or leave considerable analytical gaps. To compensate these fundamental shortcomings, it is essential to establish a better understanding of the relation between HSR station areas, place quality and quality of life.

In this paper, we analyze the development of the concept of place quality in the field of urbanism and review 44 studies and categorize the features of place quality in HSR station areas. Accordingly, this study makes two key contributions to the field. First, we propose three dimensions embraced within the concept of place quality, namely, spatial, economic, and experiential dimensions. To our knowledge, extant research on station area place quality has yet to examine these three dimensions in an integrated way. While researchers have proposed subsets of these dimensions separately. Finally, we identify gaps in the current theorization of place quality in the context of (HSR) railway station area developments and formulate directions for future research. This paper adopts the following structure. Section 2 explains how the review was conducted. Section 3 clarifies the dimension of place quality discussed in this research. Section 4 provides an overview of the literature, and the conceptualizations of place quality in the context of railway stations and in that of HSR stations. Section 5 collects features considered in previous studies of place quality definition. Section 6 is the conclusion and vision for further studies.

\section{$2 \quad$ Methodology}

To obtain an overview of the HSR station areas and place quality, Scopus, Google Scholar, and Web of Science were used to conduct a systematic literature review. A series of interrelated terms were utilized in search strings including: "high speed train" or "high speed rail," "city" or "urban," "place/spatial/urban quality," "sense of place" and "place-making." These strings have been searched for the full text review, to avoid missing potentially relevant sources. The initial search found 940 articles. However, a majority of these dealt with scales larger than the urban and included a focus on civil engineering. These articles were excluded, leading to 218 articles. In a second step, the terms evaluation," "assessment," and "best practice" were introduced into the search, and an additional 86 relevant sources were added to the dataset, bring the total to 304 . Through reviewing abstracts and cross tracing key references, 44 articles which are closely related to "place quality" and "HSR station areas" were selected for the review.

Since place quality is gradually considered as an important concept for urban land use and transportation development, the selected research literature on place quality in (HSR) station areas shows a continuously increasing trend (In Figure 1). 


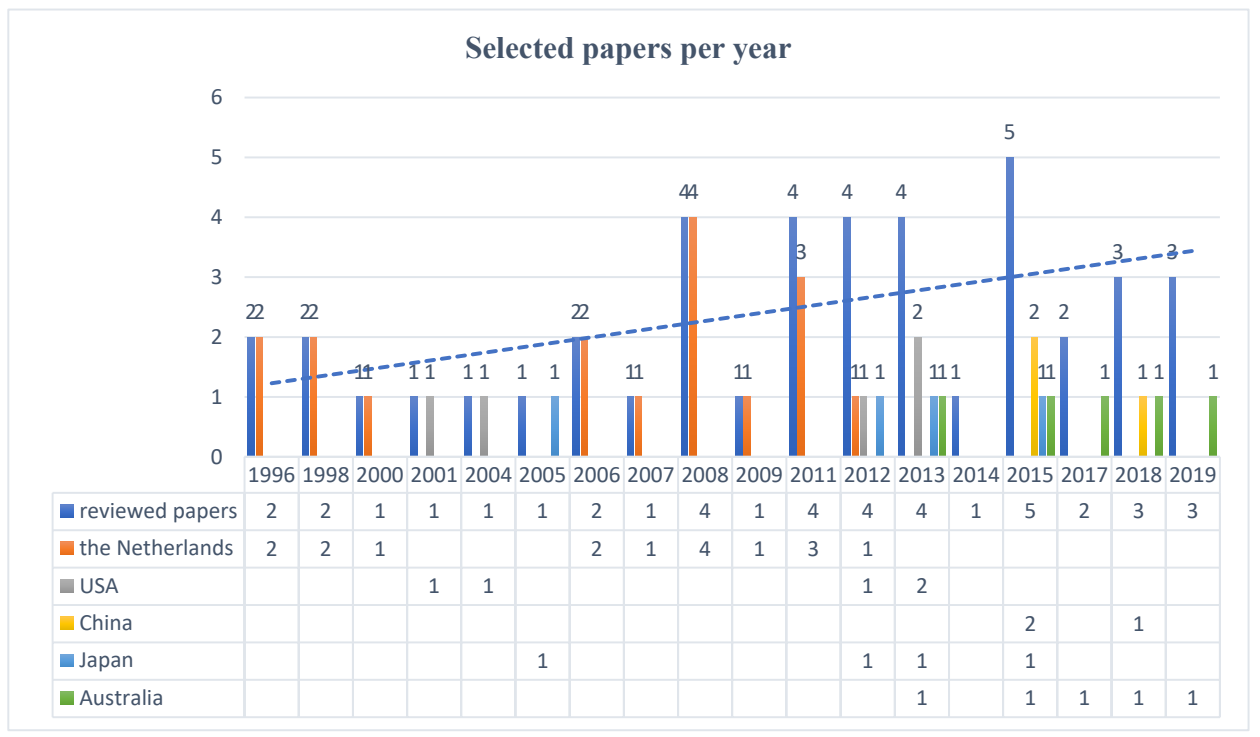

Figure 1. Trend of topics and top five countries which contribute the most papers (Source: by author)

Table 1. Distribution of papers by place quality (PQ) content

\begin{tabular}{ccc}
\hline Type of paper & Number of paper & Percentage \\
\hline Concept of PQ & $17 / 44$ & $38.64 \%$ \\
\hline $\begin{array}{c}\text { Evaluation of PQ (both conventional } \\
\text { and HSR) }\end{array}$ & $17 / 44$ & $38.64 \%$ \\
\hline HSR Best Practice (case study) & & $22.72 \%$ \\
\hline
\end{tabular}

As tables 1 shows, the papers are equally divided between papers that deal with the concept of place quality (or related terms), papers that tackle means of evaluating place quality in general and best practice in HSR station areas. Table 2 details the domain specificity of papers included. Thus, 2 of the papers deal with place quality in general, 22 deal with place quality in station areas regardless of speed, and 20 deal specifically with place quality in the context of HSR station areas. In terms of geographical distribution (Table 3.). Europe dominates the research on the topic, especially, with a significant body (17 papers) of work stemming from the Netherlands. USA, Asia and Australia separately contribute 5, 8 and 5 papers. It is noteworthy to mention that the searching process was limited to English language articles and this unavoidably biased the results (for example, the papers written in Japanese are excluded in this review). Considering our focus on providing a theoretical and empirical review, we reviewed journals, books, theses, reports and conference papers detailing the conceptualization, best practice and evaluation of place quality in (HSR) station areas. The type of publication source is shown in Table 4. 
Table 2. Distribution of papers by place quality (PQ) domain

\begin{tabular}{ccc}
\hline Type of paper & Number of paper & Percentage \\
\hline PQ in general public space & $2 / 44$ & $4.55 \%$ \\
\hline PQ in conventional rail & $22 / 44$ & $50 \%$ \\
\hline PQ in HSR & $20 / 44$ & $45.45 \%$ \\
\hline
\end{tabular}

Table 3. Geographical distribution of the selected papers

\begin{tabular}{|c|c|c|c|c|}
\hline & Country & Number of selected papers & Percentag & \\
\hline \multirow[t]{7}{*}{ Europe } & Netherlands & $17 / 44$ & $38.64 \%$ & $59.1 \%$ \\
\hline & Czech Republic & $1 / 44$ & $2.27 \%$ & \\
\hline & Switzerland & $2 / 44$ & $4.55 \%$ & \\
\hline & Spain & $2 / 44$ & $4.55 \%$ & \\
\hline & UK & $2 / 44$ & $4.55 \%$ & \\
\hline & Germany & $1 / 44$ & $2.27 \%$ & \\
\hline & Portugal & $1 / 44$ & $2.27 \%$ & \\
\hline North America & USA & $5 / 44$ & $11.36 \%$ & \\
\hline \multirow[t]{3}{*}{ Asia } & Japan & $4 / 44$ & $9.09 \%$ & $18.18 \%$ \\
\hline & China* & $3 / 44$ & $6.82 \%$ & \\
\hline & Korea & $1 / 44$ & $2.27 \%$ & \\
\hline Oceania & Australia & $5 / 44$ & $11.36 \%$ & \\
\hline
\end{tabular}

Table 4. Publication source type of the selected papers

\begin{tabular}{lll}
\hline Source & Number of selected papers & Percentage \\
\hline Journal & $20 / 44$ & $45.45 \%$ \\
\hline Book & $10 / 44$ & $22.73 \%$ \\
\hline Doctoral thesis & $5 / 44$ & $11.36 \%$ \\
\hline Conference paper & $3 / 44$ & $6.82 \%$ \\
\hline Master thesis & $3 / 44$ & $6.82 \%$ \\
\hline Institute report & $3 / 44$ & $6.82 \%$ \\
\hline
\end{tabular}

The review collected the papers focusing on scale of station area, especially the ones locate in the metropolitan centers. For example, King's Cross station area in London, Berlin Hauptbahnhof (Peters \& Novy, 2012) and Hongqiao in Shanghai (Dai, 2018), China. Although the concept is becoming more common worldwide, there are still many differences in research focus between countries. Hereby we present a brief interpretation of four representative countries from the perspective of development stages, research scales and publication forms. The Netherlands, has begun post-construction evaluation on the detailed environment level, thus offers a great deal of first-hand empirical evidence. The type of publication source is therefore diverse, including books, journals, government reports, and institute reports. Dutch articles mainly emerged in 2 time periods (1996-2000, and 2006-2012), which are associated with the publication of Node-Place theory and the implementation of the six major station redevelopment projects (officially called "New Key Projects," or "Nieuwe Sleutelprojecten [NSP]" in Dutch), such as Amsterdam Central Station and Rotterdam Central Station (Trip, 2007) . As the only 
developing country among the 12 selected countries, China began planning its high-speed rail system in the early 1990s and began operation of high-speed rail service in 2008. China is still in a period of rapid HSR development. We found many studies focusing on how to transplant the "experience" or "lessons" of implementation from European cities to Chinese cities, but predominantly not from the quality perspective, they were therefore excluded from this review. Instead, the three selected articles

are written in the decade after the construction tide, reflecting on the current poor public vitality in China's high-speed railway station area from the perspective of institutional system and space design (Dai, 2018). The papers from the USA and Australia focus on large scale HSR lines or regional network, such as California HSR system in the USA (Loukaitou-Sideris, 2013), and HSR link between Perth and Bunbury in Australia (Duckworth-Smith \& Babb, 2015). Due to their "under planning" status, the insights of place quality in the station areas are predominantly presented in the form of design proposals or planning reports.

\section{Defining place quality}

To study place quality in HSR areas, one must first define the concept in general terms regardless of its location. Literature has given a wide scope of interpretations of "place quality," include aesthetics, economics, social, political, environmental, health, well-being, and other issues (Lin et al., 2021). The review of definitions shows that elements of "place quality" are being researched widely under the terms of "quality of life" or "sense of place" or "place-making" or "urban quality" (the most four applied terms), etc. Although each field has its own preference, for example, the field of spatial planning and urban design more used to adopt "place quality" and "public space design"(Murgaš \& Klobučník, 2016), and Urban Economists use "Environment quality" and "living quality" more to describe quality-related themes, these terms, in general, vary in emphasizing spatial (Lynch, 1960; Gehl, 2001; Gehl \& Gemzøe, 2000), social (Jacobs, 1961) or economic dimensions (Andrews, 2001; Bertolini, 1996; Florida, 2004; Gospodini, 2002) associated with qualities of place (Figure 2). The spatial dimension dedicates to study the physical and visual elements that contribute to space design, since that the physical environment is believed to impact individuals' behavior and well-being (Andrews, 2001). Quality discussions from an economic perspective mainly include the flow of talents, land use and price changing, policy, etc. (Florida, 2002). The social dimension aims to reveal the relationship between quality and the sociocultural aspects, for instance, public health, wellbeing, sense of safety, etc. (Lin et al., 2021). In recent years, place quality has come to associate with environment quality (Khan et al., 2015), sustainable development (Bixel, 2014; Garau \& Pavan, 2018; Reusser et al., 2008) and smart growth debates (de Wijs et al., 2016), as well as with a shift toward planning for the new creative economies (Esmaeilpoorarabi et al., 2018a; 2018b) and neighborhoods (Leby \& Hashim, 2010). These perspectives can be seen as an in-depth discussion of economics. 


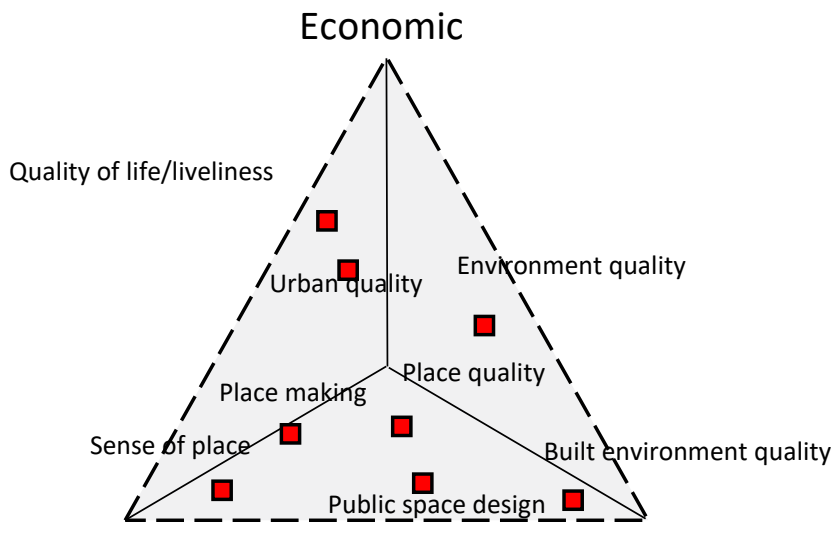

Social/Experiential

Spatial

Figure 2. The concept of place quality and its relative concepts (Source: by author)

It is worth noting that most studies have adopted a comprehensive perspective. For example, Jacobs (1961) in her famous book "Life and death of great American cities" argued that diversity is the essential element encouraging people to embrace vibrant urban life. She presents four definitions of diversity: Multiple uses (Functional diversity), Path choices (Spatial diversity), Mixture of building ages/ rents (Economic diversity), and Different purposes (User diversity). Since then, these descriptions have been firmly attached to the concept of place quality. Carmona (2019) re-ranked out the importance of elements of place quality, further linking place quality with empirical evidence. The four categories of elements he summarized: health, social, economic, and environmental aspects that together provide a relatively comprehensive framework to understand quality in general. Although these concepts are indivisible and partially overlapping (D’Alpaos \& Andreolli, 2020), we could summarized the research into place quality into three streams of thought distinguishing between: 1) Aesthetic qualities of urban spaces, 2) Experienced sense of place, 3) Agglomeration of economic activities.

\subsection{Place quality as aesthetic qualities of urban spaces (the spatial dimension)}

Early research on place quality was grounded in spatial/ urban design, emphasizing those properties of space that contribute to its legibility, and its aesthetic qualities. Lynch (1960) for instance, recognizes "paths, edges, districts, nodes, and landmarks" as the elements of a city image. Alexander et al. (1977) use pattern languages to interpret urban places. Hillier's (1996) and Hillier \& Hanson's Space Syntax $(1984,1996)$ is also a representative for this stream of thought. By calculating configurative spatial relationships in built environments, it explains how spatial typo-morphologies relate to functionality, namely movement, land use, and social wellbeing. Ewing \& Handy (2009) identified five key qualities of the built environment: imageability, enclosure, human scale, transparency, tidiness. And also, specific physical elements that contribute to these qualities. Besides, the importance of understanding the physical features is that these qualities promote to generate certain expected social behaviors (Murgaš \& Klobučník, 2016). Lately, two spatial objects that contribute to a sense of distinctive character for users got more attention, namely spatial structure of districts (Esmaeilpoorarabi et al., 2018), and street layout and design (Abdul Rahman et al., 2020). 


\subsection{Place quality as experienced "sense of place" (the experiential dimension)}

With attention starting from spatial dimension, the research interest has gradually moved to address the link between the objective environment and human experience of the environment. In the process of being used, space solidifies not just an image of a place but also its meaning in the activity patterns of people utilizing it (Rapoport, 1982). In addition, sense of place is about how a person feels about a particular physical setting (Najafi \& Shariff, 2011). Alongside tangible features, urban spaces trigger subjective responses in people navigating them, and it is feelings as well as the memories associated with urban spaces that frame a "sense of place" (Metzger, 2014). Connecting the notion of place quality as perceived and experienced sense of place to the aesthetics of place, Gehl Institute (2018) developed 12 key quality criteria to describe what makes a great urban place starting from three general perceptual qualities of place: protection, comfort, and amenities. Most criteria he proposes refers to creating an atmosphere of inviting people to use urban space as unrestricted as possible. Muleya and Campbell (2020) pointed out that the previous studies biased towards the visual sense, but the other senses should also to be considered in the public space quality measurement.

\subsection{Place quality as agglomeration of economic activities (the economic dimension)}

On the basis of the first two lenses (physical appearance and users' perception), economic attributes, as the third layer, has been clearly added to notions of place quality. Successful places are characterized not only by pleasing spatial features and unique identity, but also facilitate private as well as public benefits, and relating evidence is numerous (Beckerich et al., 2017; Lin et al., 2021; Willigers \& Van Wee, 2011; Zacharias et al., 2011). For example, studies have proved that many influencing tangible indicators of place quality such as greenery, open space, street layout, permeability, and streetscape (Lak \& Kheibari, 2020) promote business activities and gatherings of people. In Florida's creative class theory (2004), the intangible qualities that certain urban spaces provide are directly related to the overall competitiveness of cities, since these features attract creative and knowledge workers, thus boosting the economic potential of the city. Building on Florida's work, economic geographers (Kloosterman \& Lambregts, 2001) suggest that in defining place quality we should consider so-called "soft" elements, such as liveliness, culture diversity, work creativity, social tolerance, etc. Although the expression shows similarities to the second point of view, their purposes are distinct. The latter clearly aims to promote economic vitality, while the former intends to inspire people to enjoy public space freely. Although the creative class theory has been questioned and criticized, the three characteristics sorted by Florida (2002) and Trip (2008b) accurately summarize the three streams of thought: 1 ) what is there (aesthetic qualities): the built environment plus specific amenities; 2) who is there (experienced "sense of place'): the diversity of population; and 3) what is going on (agglomeration of economic activity): the combination of indoor and outdoor activities. So, by bringing together the conceptual frameworks on place quality, we aim with this study to define an

integrated conceptual framework to research and assess place quality in high density urban areas, and specifically in HSR areas.

\section{$4 \quad$ Place quality in HSR railway station areas}

The concept of place quality evolves over time in relation to the development of railway station areas. In the golden age of railway building, station buildings could be considered as a hybrid of architecture and engineering (Bertolini \& Spit, 1998). Thus, the design of station buildings and areas became more dominated by logistic considerations rather than place creation (Dales, 2011). As a consequence, railway 
station areas had become mono-functional areas, dominated by transport technologies and fragile connections to the historical city core. Nowadays, it is widely recognized that the construction of new stations, especially central ones, are strategically placed to connect the region, the city and the center itself to each other. Central place values are coming in as well as CBD like concepts and strategies (Wegener $\&$ Fuerst, 2004). Thus station areas changed from isolated transport enclaves to urban areas, combining many social, cultural and economic amenities (Figure 3), and requiring a higher quality of the public space (Bruinsma et al., 2008).
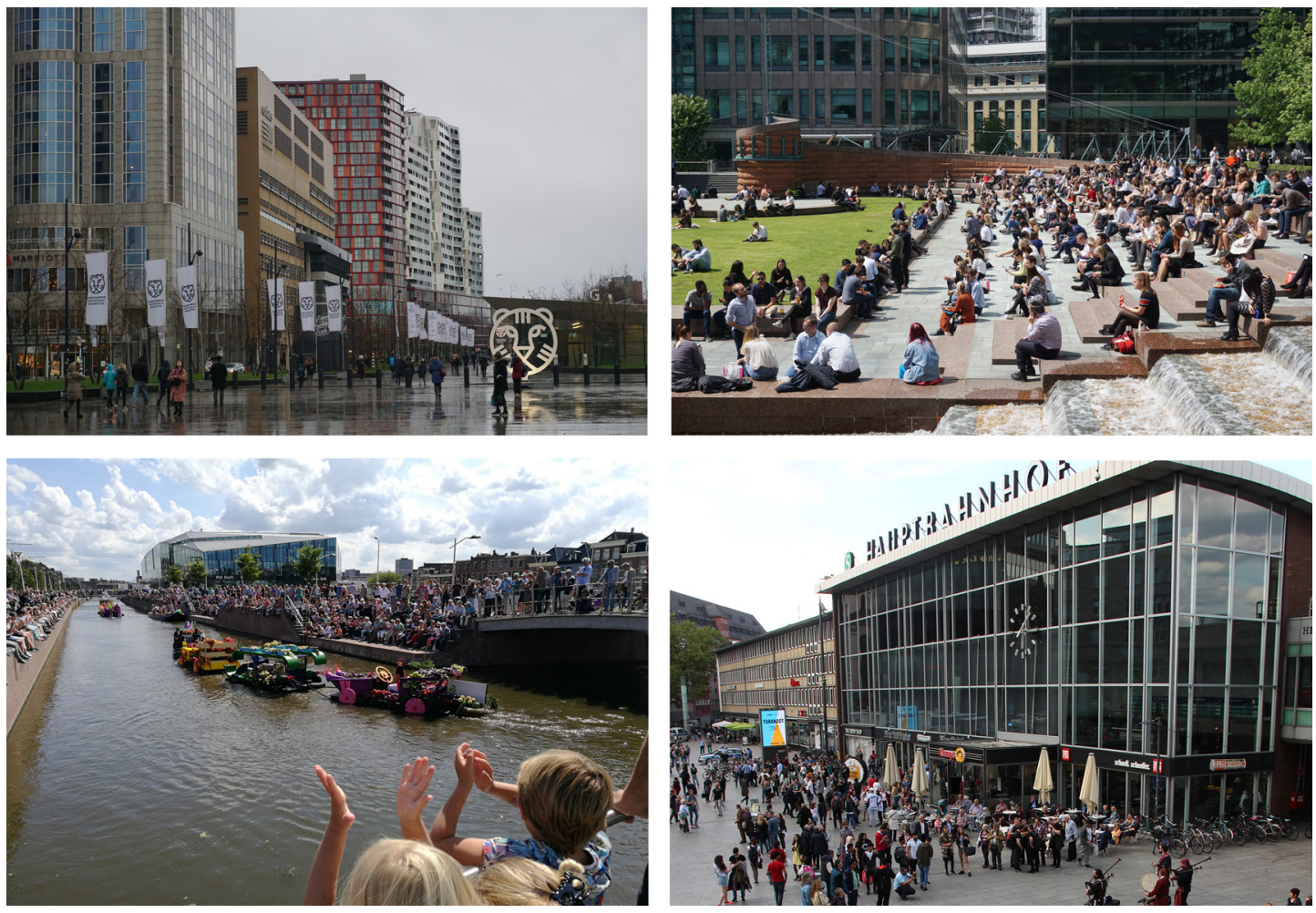

Upper left: International Film Festival Rotterdam in front of the central station district, Rotterdam; Upper right: Crowd enjoying lunch break in the square next to Liverpool Street Station, London; Lower left: Citizens watching the flower boat parade next to the Delft railway station, Delft; Lower right: Street artists performing in the square of Cologne central station, Cologne

Figure 3. Station areas with social, cultural and economic amenities (shot by author)

HSR is a new innovative railway subsystem, differentiated from the others by its speed, and with that implicitly its reach and catchment area. The UIC (In French: Union internationale des chemins de fer, the worldwide railway organization) (2018) defines a commercial speed of $250 \mathrm{~km} / \mathrm{h}$ as the principal definition for HSR. The European Union considers high-speed rail systems as specifically built lines operating at or above $250 \mathrm{~km} / \mathrm{h}$ as well as upgraded lines with speeds of $200 \mathrm{~km} / \mathrm{h}$. HSR system, compared to the conventional rail, leads to more special transport features, such as larger passenger volumes, more integration with other transport modes, connecting multiple local, regional and (inter-) national transport networks (Peters, 2009). To address these tasks, scholars have further considered place quality in HSR developments built on the reflections of the quality in conventional station areas. The current debate on place quality in relation to HSR station areas in particular is centered within 3 fields of study: transport planning and land use (including a large body of literature on the node-place model 
and a smaller one considering TOD in more general terms), urban design (including articles on urban and spatial quality as well as articles focused on place-making), urban economics (including articles on creative class and mega-project management). There exists a strong synergy between them, but also that these fields have understood and defined place quality in very different ways.

This section reviews the notions of place quality developed by previous studies, focusing on HSR station areas, as particular mobility infrastructures that is a hybrid of transport, service, and multi-cultural public space (Nag, et al., 2019), but recognize also that many of the characteristics of place quality in conventional station areas also apply to HSR station areas. Thus, we draw on established models from TOD and node-place theory proposed by Bertolini (1999), to develop our theoretical framework based on the three perspectives mentioned above, namely the spatial, the economic and the experiential.

\subsection{Place quality as agglomeration of economic activities (the economic dimension)}

Focusing directly on transport hubs as relevant urban places to understanding the relationship between transport accessibility (transport demand) and development pressure (economic activity patterns), the HSR supposes to maximize benefits and capture value the most (Nuworsoo \& Deakin, 2009). TOD certainly is one of the most representative models of transport area development, and is commonly defined as a compact, mixed-use and walkable development around transit facilities (Cervero, 2004). Founded on the " 3 Ds" (density, diversity, and design), the concept was later supplemented to "5 Ds" by adding destination accessibility and distance to transit (Cervero \& Kockelman, 1997; Ewing \& Cervero, 2001; Ewing \& Cervero, 2010). From the inception of TOD thinking and practice, the focus has changed from transit to economic development. While the original concept focused on reducing car dependency and switching to more sustainable modes of transport (Bernick \& Cervero, 1998), economic development quickly became an important second goal. An American national survey even suggests that TOD is primarily focused on boosting ridership, and thereby revenue income (Cervero, 2004). Jacobson and Forsyth (2008) stated the prior studies on TOD that have tended to discuss policy issues and financing but still require supplementary studies on place-making. In the latest literature review of TOD (Ibraeva et al., 2020), the similar conclusion was claimed: except the papers about travel behaviors, the effects of TOD on real-estate prices are the most studied. Compared with conventional ones, the large-scale, complexity of the undertaking, long development and building time, large number of stakeholders with competing interests warrants the inclusion of HSR station under the category of a mega-project (Peters \& Novy, 2012). Studying HSR station areas as manifestations of mega-project development, Jacobs (2012) questions place quality as an element of the planning process and focuses on how the concept differs according to the different stakeholders involved in that process. Due to the large number of public and private parties involved in the development of HSR projects, and their divergent interests and ambitions, coherent approaches to place quality are difficult to achieve (Chen et al., 2019). Given the enormous financial and political resources injected into HSR projects, studies emphasized the importance of better integration with the urban system, both spatially and institutionally (Dai, 2018).

Another exploration of place quality in relation to railway stations is the node-place model. Bertolini (1996) conceptualized railway stations as "node" - emphasizing the infrastructural and transport role of the station, and "place" - emphasizing the qualities of surrounding urban space. This model has clearly revealed the dual role of stations but defines "place" relatively narrow. In the original proposition of node-place model, place value is simplified to an index of economic development, mainly referring to three indicators: number of residents, number of shops and other commercial functions, and the mix of these functions. If we consider transportation as a part of the economy, since the economic success of the TOD is directly depending on the level of connectedness from (inter-)national to local multi-modal transportation networks, the later researches (Grigolon et al, 2016; Kloosterman \& Lambregts, 2001; 
Peek et al., 2006; Peek \& Louw, 2008) could be simply recognized as strengthening the traditional economic lens. Peek and Van Hagen (2002) presented recommendations for railway station areas by creating synergy between node value and place value, and highlighted that place value offers a longer-term positive effect on urban economic development than node value does. Chorus and Bartolini (2011) applied it to investigate urban development (floor area ratio as the indicator) of Japanese station neighborhoods, and Duckworth-Smith \& Babb (2015), Babb et al. (2016), and Olaru et al.(2019) brought it to Perth, Australia.

Even when the model has been applied to different cities and countries, the mainstream research repeatedly narrows the "place quality" to the "economic lens." For developing sub-centers, government investment and private investment usually funds large real estate projects in HSR areas. Thus, both conventional station cases and HSR cases are normally mono-functional, privatized areas of office districts that feel hardly really "urbanized" (Majoor \& Schuiling, 2008). Practical experience also proved that if station developments only considered the economic value, excluding social, cultural and environmental benefits, there will be a danger of creating failed public spaces, further leading to a result that the economic objectives will be not to achieved either (Pugalis, 2009). Anciaes and Jones (2020) further pointed out the bottleneck of monetizing transport hubs, that is, it may fit well with national guidelines but hard to benefit the city and smaller level. And at the meantime, the "traffic nodes" attributes contribute more complexity to their development process (Peters \& Novy, 2012). According to Bartolini's theory, the higher level of node-value creates more place-value (i.e., economic value) (Bertolini, 1999). Thus, HSR stations have more potential to become a metropolitan area that fosters comprehensive development, first and foremost economically but in potential also spatially and socially (Majoor \& Schuiling, 2008).

\subsection{Place quality as aesthetic qualities of urban spaces (the spatial dimension)}

Apart from economic development focused literature regarding place quality in railway station areas, a group of researchers that have focused to some extent on the station typology and its strategic position in the transport network, contributing to developing the spatial dimension of place quality. For example, Trip (2007) related the issue of place quality to the issues of scale. As a multiscale concept, many elements of place quality are relevant on multiple levels, but they play out differently on various scales. This sight remains in both research of conventional railways and HSR ones. Nuworsoo \& Deakin (2009) sorted out two groups of factors that contribute to station area success: 1 ) those related to the broader "station area" ( District scale), and 2) those related to "station layout" (Building scale). Zemp (2011) introduced three station functions depending on the position of the station in urban fabric: integrating multiple transport modes for small-sized stations; providing commercial and leisure functions for medium-sized stations; and playing the role of a city center in large ones. When it comes to HSR station areas, the combination of speed, reach and catchment areas implies that they are definitely of another scale than traditional railway station areas: they are urban mega-projects. Therefore, achieving place quality in HSR projects faces more severe challenges from the passenger volume (Kim et al., 2018), the special travel request (Chen \& Wei, 2013), and the strategic position within both urban and regional structures and transport networks (Loukaitou-Sideris et al., 2017), etc. Loukaitou-Sideris et al., (2017) linked the quality making with four spatial levels: the station, station-neighborhood, urban, and region. They pointed out the different aims should be settled for different levels, the connections between stations and their transport network should be well-designed at the urban and region level. And emphasized that the importance of the functionality, and urban design at small-scale levels to reduce motorized traffic volumes and speeds.

Different from Europe, where HSR development are firmly integrated into existing centers, China, as a developing country, has an intense debate about whether to place HSR stations in the urban centers 
or urban fringes in terms of the HSR system expansion. Thus, Chinese scholars focus intently to associate the place quality with the strategic location of HSR station, and more clearly on railway station areas as unique urban settings with large-scale and strong multimodal transport features. Wang (2014) pointed out that previous studies still overlook station's particularity as transportation hubs, particularly in HSR context: He argue that transport infrastructure overwhelmingly occupies space in station areas. Stations link not only large-scale transportation infrastructure but also different modes of transport. Finally, spatial elements, such as visual axes, public squares should also be considered within the context of this overwhelming focus on infrastructure. Chen and Wei (2013) concluded three features of Chinese HSR projects: suburbanization, large-scale and airport-style mode, which are basically the opposite features to a high-quality environment, hustle and bustle, human scale and integration with the surroundings. Meanwhile, even though the node quality could be still reasonably improved by transport planning, it is almost impossible to achieve place quality in a short time, and will be challenging and time-consuming to connect these transport hubs with the existing city centers (He, 2016). Dai (2018) also concluded that from a place-making and institutional perspective place quality in Chinese HSR station developments consists of four elements: location, infrastructure and spatial integration, functional diversity, and sustainability. Location, as the most important one, could fundamentally influence the quality performance of HSR areas.

Covered by the spatial structural umbrella, scholars propose sub-categories and indicators of place quality. And their studies with the spatial aesthetic lens show a common feature: strongly influenced by the economic development lens. The two lenses thus overlap in parts, which refers many spatial indicators were interpreted from the perspective of how they affect economic performance. For example, Rond (2011), Kamruzzaman et al. (2014) illustrate six objectively quantified indicators of place quality: job density, residential density, land-use diversity, intersection density, cul-de-sac density, and accessibility. Japanese scholars have come up with the concept of rail integrated communities (RIC) (Calimente, 2012) to describe the privatization of station neighborhoods' development, based on the TOD idea. Hence, their studies relate more to walkability (Kido, 2015; Zacharias et al., 2011), and aesthetics of the living environment (Kido, 2005) in terms of place quality. In the City-Hub model, Monzón et al. (2016) identified two groups of features for transportation hubs: spatial aspects and local impacts, and come up with three overarching elements connected to place quality: building design, stakeholder involvement, and business model.

\subsection{Place quality as experienced "sense of place" (the experiential dimension)}

Even though the basic functional spatial layout and the transport integration within HSR show a high degree of similarity with research on conventional train station areas, the difference appears in the form of additional service upgradation (Nag et al., 2019). More and more studies thus have noticed insufficient attentions on the experience lens. Kloosterman and Trip (2011) start from the urban design field and then introduce a series of social indicators such as diversity, and integration into the description of place quality. Eboli and Mazzulla (2011), Groenendijk et al. (2018) suggested to add the travelers' experience value, as a new dimension, to extend the existing node-place model to more accurately evaluate the quality of a station area. Similar supplementary research is also being carried out in the TOD field. Since the concept of place quality under TOD research has continuously concentrated on economic lens (transfer quality, spatial quality, and development intensity), only few studies focus on the experience lens, namely residential location, urban form, and community life (Ibraeva et al., 2020). Cervero and Day (2008) proposed 56 indicators to evaluate the effect of TOD projects worldwide, includes some non-morphological interpretations of place quality, namely authenticity, tolerance, street life, buzz, urbanity. Social justice and freedom of choice are also considered to be essential. It is worth noting that, 
the primary goal of TOD is concentrating urban activities, and boosting the economic potential of the surroundings of all kinds of transport nodes, not specifically for railway areas. Therefore, place quality is a by-product of TOD not a primary aim. Even when "place attributes" are present in TOD assessments they are usually marginal. Instead, the primary emphasis is on land-use and economic performance. Place quality is easy to ignore in customary cost-benefit analyses in the context of TOD development as indicators are usually difficult to express in monetary terms (Bruinsma et al., 2008). This reminds us that the study of TOD and place quality in station areas fundamentally aim in different directions, even though their principles show similarities.

There are only few literatures that clearly study the experience of place quality within HSR areas. Trip (2007) first confirmed the usefulness of place quality as a sophisticated concept that connects the economy to urban development and is more specific than its comparable concepts such as quality of life or urban quality. He used the cases of Amsterdam and Rotterdam to develop ten indicators of place quality in HSR station areas. Except for spatial dimension (spatial integration, location of functions) and economic dimension (real estate, quality of functions, functional integration), He highlighted the effect of design, namely architecture and building materials, urban design, public space, and third spaces. Trip (2008a) clustered these indicators into four main categories: urban structure, architecture, functional diversity, and the quality of public space. Groenendijk et al. (2018) added indicators in terms of user experience, such as comfort, personnel presence, and environmental aesthetics. From these indicators and categories, the economic lens and aesthetic lens stand clearly out, but still the experience lens plays a small proportion.

To sum up, the development of place quality as a concept in (HSR) railway station research has predominantly focused on the economic dimension of place quality, featuring a dominant preoccupation with land-use, accessibility and economic performance. Given the strategic and logistic role of station areas within the urban fabric, it is not surprising that the economic lens dominates the bulk of the research, understanding place quality as the agglomeration of economic activities. Both TOD and Node-Place start off as economic-logistic-land use interpretations of place quality. Only later generations of researchers started to widen the interpretation into the other two lenses, spatial one, and experiential one. When considering the aesthetic lens of place quality in railway station areas regardless of speed, the research is relatively adequate, some notions, such as orientation, connection with the urban structure and the spatial elements relate to accessibility have been stressed in relation to the spatial design of station buildings and squares. What is heavily under-studied, is experience as a dimension of place quality, namely the idea that station areas should be designed and experienced as urban places, affording urban identity and a "sense of place" (Figure 4, left).
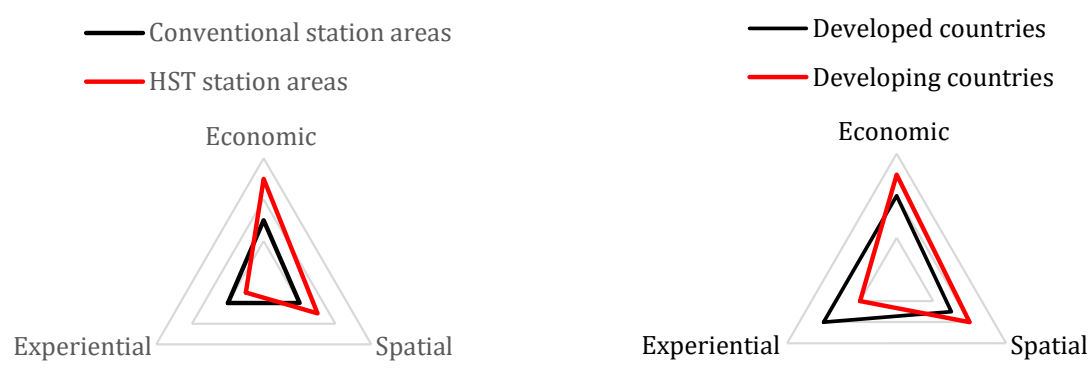

Figure 4. Comparison between conventional/ HSR station areas, and developed/developing countries 
Furthermore, we recognize a dynamic change of focus among the three dimensions from the temporal point of view. HSR station areas in suburbs or undeveloped areas, particularly in developing countries, are used at a low rate and used by monotonous user group, which means high demands for place quality may not be apparent yet. While the central station areas and stations in the developed countries stress more to fulfil users" needs, since the land use and transport network have been already relatively formed. This possibly interprets that why developed countries pay more attention to the study of place quality, particularly to the experiential dimension, than the developing countries do (Figure 4, right). It is foreseeable that with the spatial interventions implemented and land use adjusted, the demand for and attention to the place quality in developing countries probably will shift from the economic lens and the spatial lens to the experiential lens (Caset et al., 2019; Rodríguez \& Kang, 2020).

\section{$5 \quad$ The features of place quality}

Based on articles reviewed, we identified a series of relevant features of place quality in HSR station areas (Table. 5). Features were grouped based on the three dimensions of place quality identified in the working definition. Even though scholars have been adopting different expressions to describe the features of quality, based on the differences of research focus in object, perspective, timeframe, scale level, and indicator type, we found that studies analyzing conventional and HSR station areas showed a high degree of continuity. Features of place quality identified in conventional station areas are mostly applicable to the HSR context, while some features acquire a different salience in the context of HSR.

Features of place quality acquire different nuances depending on scale. However, there exists a strong synergy between scales reflected in economic dimension. On the regional scale, the relationship between strategic location, transport planning, and governance is particularly important to establishing high-quality station areas. Thus, the success of a HSR development is generally evaluated by its economic performance. This is particularly the case in HSR stations given higher development ambitions.

On the urban and district scales, the quality features from spatial and economic dimension function collaboratively, mainly aiming to reduce the barrier effect caused by the existence of railway facilities and vehicles, to connect with the existing economic vitality area, especially in terms of the slow traffic (pedestrian and bicycle), and also to create a shopping friendly atmosphere. These have been inclusively indicated in both contexts. However, in the context of HSR station areas more intangible values and subjective experience features were identified and highlighted as relevant to city branding.

When comes to the building scale, qualities mainly refer to environmental comfort, satisfaction with amenities, and aesthetics. These features are influenced by the spatial elements but are more relevant to the user's subjective experience. Though the level of amenities and services that HSR station areas can provide have been upgraded, the core functions and basic needs of users remain the same. This focus, thus, did not show significant differences in academic research, but applied to both conventional rail and HSR. 


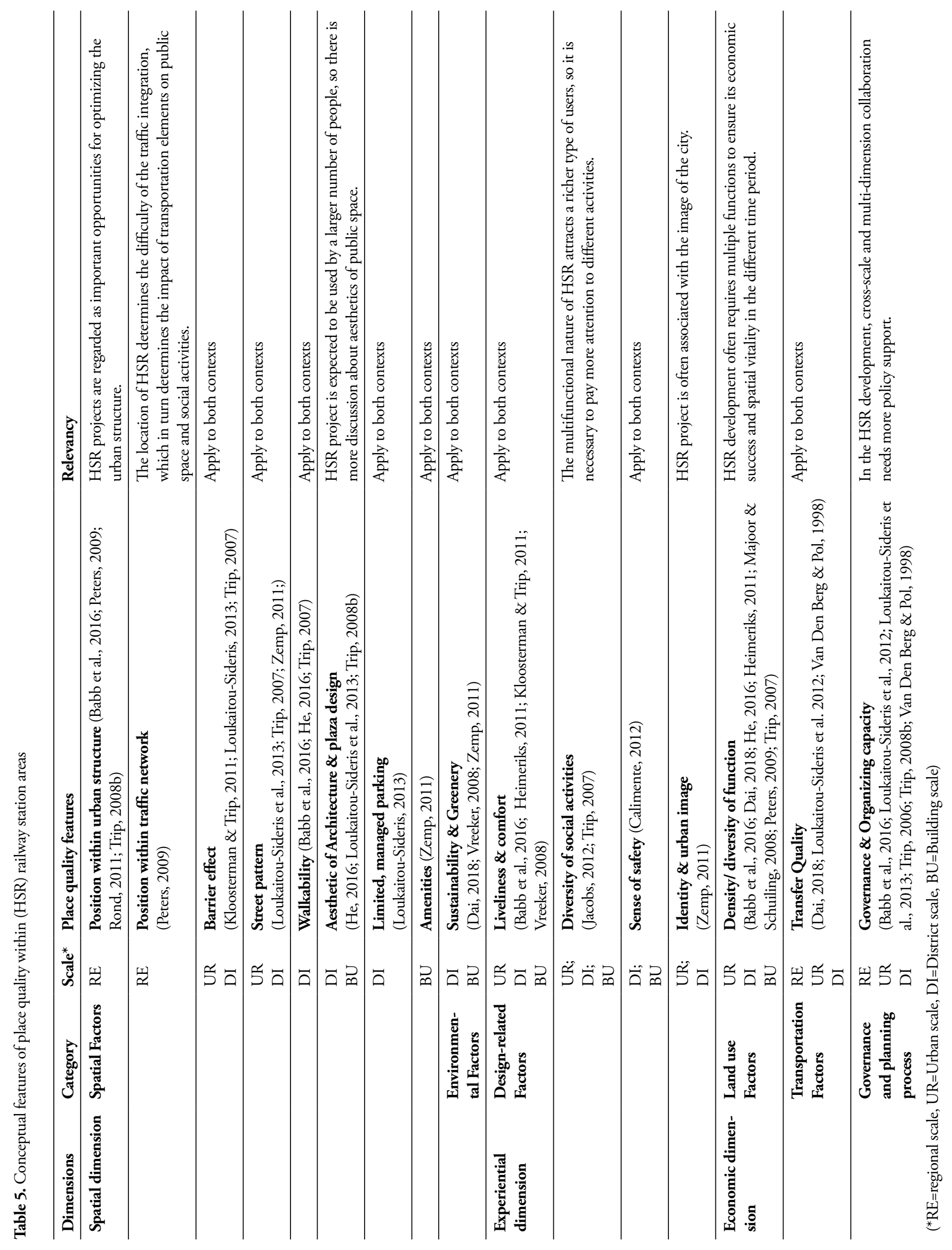




\section{Discussion and conclusion}

In this article, we built on place quality theories in urbanism to formulate a working definition of the concept and apply it to the study of (HSR) station areas, identifying three dimensions commonly associated with the quality of place: 1) a spatial dimension associated with the aesthetic qualities of urban spaces, 2) A socio-psychological dimension associated with experienced "sense of place," and 3) an economic dimension associated with the agglomeration of economic activities. In Figure 5, the main streams of thoughts and theories (left-hand side) have been related to the three lines of inquiries in railway station area research (right-hand side). Since the development of railway station areas is predominantly conceptualized as an interplay between transport and land use, we concluded that the economic dimension by far outweighs the other two in academic debates, with the dominant theories all being eminently concerned with land use and economic performance. If these two do get the attention they are conceptualized to serve the dominant economic lens. The spatial, aesthetic features of place quality have to a certain extent tackled the qualities associated with railway station areas, solving issues related to the barrier effect of transport infrastructure, but also more site-specific problems related to pedestrian flows. According to Tonkiss (2009), public space could be divided into three types, namely square, cafe and street. And station areas are the combination of these three, which give them an important role in urban public life. But the experiential dimension of place quality remains vague and insufficiently developed in railway station areas research. The experiential dimension is researched more as a secondary condition of contributing to economic development. Thus, both conceptualizations of this dimension and efforts at operationalizing it to enable better urban planning and design have remained inadequate. Finally, we collected a preliminary set of conceptual features, drawing on the literature, and categorizing features of place quality according to the three dimensions of our definition. The results of the classification also confirmed the conclusion above.

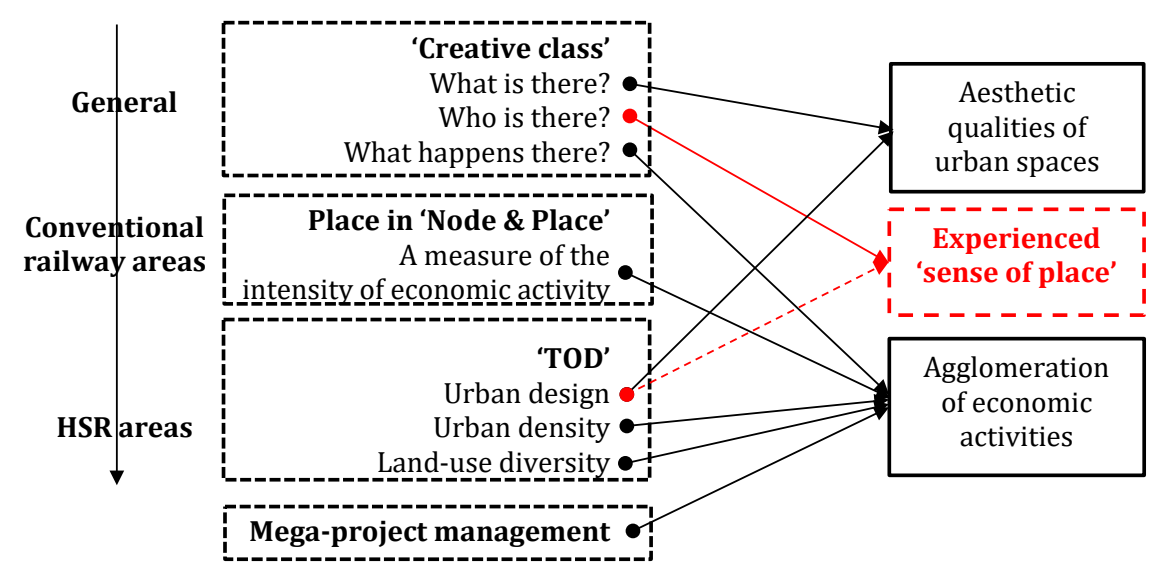

Figure 5. The three aspects of place quality and their corresponding theories/models (Source: by author)

Due to its spatial, functional scale and systemic complexity as well as divergent actors, processes, and interests involved, there are even more challenges and potentials for the HSR station areas. At the same time, the strategic position of the HSR for urban renaissance creates potentially a strong urge for integrating them into the local urban tissue and uses, contributing to not only economic resilience but also the quality of life and the identity of city. As for further research, since we have known that the crux 
of the problem is the deviancy between three perspectives, we should especially strengthen the understanding of the experience lens in HSR station areas. How do users experience in situ the place quality of HSR station areas, how do designers currently interpret place quality experience, and how could the indicators of framework related to the experience of HSR station areas be operationalized for an empirical assessment? These questions for further studies could help us complete the conceptualization of place quality in HSR station areas, facilitate more in-depth academic research, and evidence-based guidelines for the design and planning of HSR station areas. 


\section{References}

Abdul Rahman, N., Ghani, I., Teh, M. Z., \& Ibrahim, K. A. (2020). Rethinking urban public space: Physical and functional analysis through visual surveys. IOP Conference Series: Earth and Environmental Science, 409(1), 012002. https://doi.org/10.1088/1755-1315/409/1/012002

Alexander, C., Ishikawa, S., Silverstein, M., Jacobson, M., Fiksdahl-King, I., \& Shlomo, A. (1977). A pattern language: Towns, buildings, construction. Berkeley, CA: Center for Environmental Structure.

Anciaes, P., \& Jones, P. (2020). Transport policy for liveability - Valuing the impacts on movement, place, and society. Transportation Research Part A: Policy and Practice, 132(November 2019), $157-$ 173. https://doi.org/10.1016/j.tra.2019.11.009

Andrews, C. J. (2001). Analyzing quality-of-place. Environment and Planning B: Planning and Design, 28(2), 201-217. https://doi.org/10.1068/b2714

Babb, C., Falconer, R., Olaru, D., Duckworth-Smith, A., \& Isted, R. (2016). Transport and land-use functions of four rail station configurations in Perth. In S. Biermann, D. Olaru, \& V. Paul (Eds.), Planning boomtown and beyond (pp. 436-459). Perth, Australia: UWA Publishing.

Balducci, A., and Bertolini, L. (2007). Reflecting on practice or reflecting with practice? Planning Theory and Practice, 8(4), 532-555. https://doi.org/10.1080/14649350701664770

Beckerich, C., Benoit-Bazin, S., \& Delaplace, M. (2017). Does high speed rail affect the behavior of firms located in districts around central stations? The results of two surveys conducted in Reims in 2008 and 2014. Transportation Research Procedia, 25, 3017-3034. https://doi.org/10.1016/j. trpro.2017.05.287

Bernick, M., \& Cervero, R. (1998). Transit villages in the 21st century. Economic Geography, 74(4), 440-442. https://doi.org/10.2307/144337

Bertolini, L. (1999). Spatial development patterns and public transport: The application of an analytical model in the Netherlands. Planning Practice and Research, 14(2), 199-210. https://doi. org/10.1080/02697459915724

Bertolini, L. (1996). Nodes and places: Complexities of railway station redevelopment. European Planning Studies, 4(3), 331-345. https://doi.org/10.1080/09654319608720349

Bertolini, L. (1998). Station area redevelopment in five European countries: An international perspective on a complex planning challenge. International Planning Studies, 3(2), 163-184. https://doi. org/10.1080/13563479808721707

Bertolini, L. (2000). Planning in the borderless city: A conceptualization and an application to the case of station area redevelopment. The Town Planning Review, 71(4), 455-475. https://doi.org/10.3828/ tpr.71.4.2883q121q1671185

Bertolini, L., \& Spit, T. (1998). Cities on rails—The redevelopment of railway station areas. Abingdon-onThames, UK: Routledge.

Bixel, E. (2014). Sustainability or connectivity? The neoliberal logics of train station area development. Critical Planning, 21(1), 99-121.

Bruinsma, F., Pels, E., Priemus, H., Rietveld, P., \& Van Wee, B. (2008). Railway development: Impacts on urban dynamics. New York: Springer. https://doi.org/10.1007/978-3-7908-1972-4

Calimente, J. (2012). Rail integrated communities in Tokyo. Journal of Transport and Land Use, 5(1), 19-32. https://doi.org/10.5198/jtlu.v5i1.280

Carmona, M. (2019). Place value: Place quality and its impact on health, social, economic, and environmental outcomes. Journal of Urban Design, 24(1), 1-48. https://doi.org/10.1080/13574809.20 18.1472523

Caset, F., Teixeira, F. M., Derudder, B., Boussauw, K., \& Witlox, F. (2019). Planning for nodes, places, and people in Flanders and Brussels: An empirical railway station assessment tool for strate- 
gic decision-making. Journal of Transport and Land Use, 12(1), 811-837. https://doi.org/10.5198/ jtlu.2019.1483

Cervero, R., \& Day, J. (2008). Suburbanization and transit-oriented development in China. Transport Policy, 15(5), 315-323. https://doi.org/10.1016/j.tranpol.2008.12.011

Cervero, R., \& Kockelman, K. (1997). Travel demand and the 3Ds: Density, diversity, and design. Transportation Research Part D: Transport and Environment, 2(3), 199-219. https://doi.org/10.1016/ S1361-9209(97)00009-6

Cervero, R., Murphy, S., Ferrell, C., Tsai, Y.-H., Arrington, G. B., Boroski, J., ... Witenstein, N. (2004). Transit-oriented development in the United States: Experiences, challenges, and prospects. Washington, DC: The National Academies Press. https://doi.org/10.17226/23360

Chen, C. L., Loukaitou-Sideris, A., de Ureña, J. M., \& Vickerman, R. (2019). Spatial short and longterm implications and planning challenges of high-speed rail: A literature review framework for the special issue. European Planning Studies, 27(3), 415-433. https://doi.org/10.1080/09654313.2018 .1562658

Chen, C. L., \& Wei, B. (2013). High-speed rail and urban transformation in China: The case of hangzhou east rail station. Built Environment, 39(3), 385-398. https://doi.org/10.2148/benv.39.3.385

Chorus, P., \& Bertolini, L. (2011). An application of the node place model to explore the spatial development dynamics. Journal of Transport and Land Use, 4(1), 45-58. https://doi.org/10.5198/jtlu. v4i1.145

Conticelli, E., \& Tondelli, S. (2013). Railway stations between infrastructural complexity and architectural form. In Structures and architecture (pp. 751-756). Amsterdam: Elsevier. https://doi. org/10.1201/b15267-105

D'Alpaos, C., \& Andreolli, F. (2020). Urban quality in the city of the future: A bibliometric multicriteria assessment model. Ecological Indicators, 117, 106575. https://doi.org/10.1016/j. ecolind.2020.106575

Dai, G. (2018). Place-making around high-speed railway stations in China. Amsterdam: University of Amsterdam.

Dales, J. (2011). Urban realm around the station. Urban Design Group, 120, 23-26.

de Wijs, L., Witte, P., \& Geertman, S. (2016). How smart is smart? Theoretical and empirical considerations on implementing smart city objectives - A case study of Dutch railway station areas. Innovation, 29(4), 422-439. https://doi.org/10.1080/13511610.2016.1201758

Du, J., Druta, O., Berg, P. Van Den, and Wesemael, P. J. V. Van. (2021). How do socio-demographic characteristics affect users' perception of place quality at station areas? Evidence from Amsterdam, The Netherlands. Urban Science, 5(80), 19. https://doi.org/https://doi.org/10.3390/urbansci5040080

Duckworth-Smith, A., \& Babb, C. (2015). Indicating quality of place for station precinct development: Enhancing 'Place' in the placelnode model. Paper presented at the State of Australian Cities Conference 2015, Gold Coast, Australia. Retrieved from https://espace.curtin.edu.au/handle/20.500.11937/45127

Eboli, L., \& Mazzulla, G. (2011). A methodology for evaluating transit service quality based on subjective and objective measures from the passenger's point of view. Transport Policy, 18(1), 172-181. https://doi.org/10.1016/j.tranpol.2010.07.007

Esmaeilpoorarabi, N., Yigitcanlar, T., \& Guaralda, M. (2018a). Does place quality matter for innovation districts? Determining the essential place characteristics from Brisbane's knowledge precincts. Land Use Policy, 79(September), 734-747. https://doi.org/10.1016/j.landusepol.2018.09.016

Esmaeilpoorarabi, N., Yigitcanlar, T., \& Guaralda, M. (2018b). Place quality in innovation clusters: An empirical analysis of global best practices from Singapore, Helsinki, New York, and Sydney. Cities, 74(November 2017), 156-168. https://doi.org/10.1016/j.cities.2017.11.017

Esmaeilpoorarabi, N., Yigitcanlar, T., Guaralda, M., \& Kamruzzaman, M. (2018). Evaluating place 
quality in innovation districts: A Delphic hierarchy process approach. Land Use Policy, 76(February), 471-486. https://doi.org/10.1016/j.landusepol.2018.02.027

Ewing, R., \& Cervero, R. (2001). Travel and the built environment: A synthesis. Transportation Research Record, 1780, 87-114. https://doi.org/10.3141/1780-10

Ewing, R., \& Cervero, R. (2010). Travel and the built environment. Journal of the American Planning Association, 76(3), 265-294. https://doi.org/10.1080/01944361003766766

Ewing, R., \& Handy, S. (2009). Measuring the unmeasurable: Urban design qualities related to walkability. Journal of Urban Design, 14(1), 65-84. https://doi.org/10.1080/13574800802451155

Florida, R. (2002). The rise of the creative class: And how it's transforming work, leisure, community, and everyday life. New York: Basic Books.

Florida, R. (2004). Cities and the creative class. New York: Routledge. https://doi. org/10.4324/9780203997673

Garau, C., \& Pavan, V. M. (2018). Evaluating urban quality: Indicators and assessment tools for smart sustainable cities. Sustainability (Switzerland), 10(3), 575. https://doi.org/10.3390/su10030575

Gehl Institute. (2018). Twelve quality criteria. Retrieved from https://gehlinstitute.org/wp-content/uploads/2017/08/QUALITY-CRITERIA-FINAL.pdf

Gehl, J. (2001). Life between buildings: Using public space. Copenhagen: The Danish Architectural Press.

Gehl, J., \& Gemzøe, L. (2000). New city spaces. Copenhagen: The Danish Architectural Press.

Gospodini, A. (2002). European cities in competition and the new "uses" of urban design. Journal of Urban Design, 7(1), 59-73. https://doi.org/10.1080/13574800220129231

Grigolon, A., Singh, Y. J., Koeva, M., \& Madureira, M. (2016). Transit-oriented development (TOD) assessment using 3D visualisation and modelling: Prospects and opportunities. Design and Decision Support Systems in Architecture and Urban Planning - 13th International Conference on Design and Decision Support Systems in Architecture and Urban Planning, Eindhoven, Netherlands.

Groenendijk, L., Rezaei, J., \& Correia, G. (2018). Incorporating the traveler's experience value in assessing the quality of transit nodes: A Rotterdam case study. Case Studies on Transport Policy, 6(4), 564-576. https://doi.org/10.1016/j.cstp.2018.07.007

He, S. (2016). Between permeability and isolation: A comparative urban life study of inner-city railway stations and their node precincts in China. Athens Journal of Architecture, 2(2), 107-130. https://doi. org/10.30958/aja.2-2-2

Heimeriks, D. (2011). From transfer node to urban node traffic light method. Delft: Delft University of Technology.

Hillier, B. (1996). Space is the machine: A configurational theory of architecture. Cambridge, UK: Cambridge University Press.

Hillier, B., \& Hanson, J. (1984). The social logic of space. Cambridge, UK: Cambridge University Press.

Ibraeva, A., Correia, G. H. de A., Silva, C., \& Antunes, A. P. (2020). Transit-oriented development: A review of research achievements and challenges. Transportation Research Part A: Policy and Practice, 132, 110-130. https://doi.org/10.1016/j.tra.2019.10.018

Jacobs, J. (1961). The death and life of great American cities. New York: Random House.

Jacobs, W. (2012). Tendering quality redevelopment of railway stations. Utrecht, Netherlands: Utrecht University.

Jacobson, J., \& Forsyth, A. (2008). Seven American TODs: Good practices for urban design in transit-oriented development projects. Journal of Transport and Land Use, 1(2), 51-88. https://doi. org/10.5198/jtlu.v1i2.67

Kamruzzaman, M., Baker, D., Washington, S., \& Turrell, G. (2014). Advance transit-oriented development typology: Case study in brisbane, Australia. Journal of Transport Geography, 34, 54-70. https:// doi.org/10.1016/j.jtrangeo.2013.11.002 
Khan, M. F., Aftab, S., \& Habiby, F. (2015). Quality of urban environment: A critical review of approaches and methodologies. Current Urban Studies, 3(04), 368-384. https://doi.org/10.4236/ cus.2015.34029

Kido, E. M. (2005). Aesthetic aspects of railway stations in Japan and Europe, as a part of context sensitive design for railways. Journal of the Eastern Asia Society for Transportation Studies, 6, 4381-4396. https://doi.org/10.11175/easts.6.4381

Kido, E. M. (2015). New large urban and regional railway stations reflecting new age. Retrieved from http://www.ctie.co.jp/kokubunken/

Kim, H., Sultana, S., \& Weber, J. (2018). A geographic assessment of the economic development impact of Korean high-speed rail stations. Transport Policy, 66, 127-137. https://doi.org/10.1016/j. tranpol.2018.02.008

Kloosterman, R. C., \& Lambregts, B. (2001). Clustering of economic activities in polycentric urban regions: The case of the Randstad. Urban Studies, 38(4), 717-732. https://doi. org/10.1080/00420980120035303

Kloosterman, R. C., \& Trip, J. J. (2011). Planning for quality? Assessing the role of quality of place in current Dutch planning practice. Journal of Urban Design, 16(4), 455-470. https://doi.org/10.108 $0 / 13574809.2011 .585863$

Lak, A., \& Kheibari, S. Z. (2020). Towards a framework for facilitating the implementation of tactical urbanism practices: Assessment criteria in the place-making approach in Iran. Geoforum, 115(July), 54-66. https://doi.org/10.1016/j.geoforum.2020.07.003

Leby, J. L., \& Hashim, A. H. (2010). Liveability dimensions and attributes: Their relative importance in the eyes of neighbourhood residents. Journal of Construction in Developing Countries, 15(1), 67-91.

Lin, S., Dhakal, P. R., \& Wu, Z. (2021). The impact of high-speed railway on China's regional economic growth based on the perspective of regional heterogeneity of quality of place. Sustainability, 13(9), 4820.

Loukaitou-Sideris, A. (2013). New rail hubs along the HSR corridor in California: The urban design challenges. Transportation Research Record: Journal of the Transportation Research Board, 2350, 1-8. https://doi.org/10.3141/2350-01

Loukaitou-Sideris, A., Cuff, D., Higgins, T., \& Linovski, O. (2012). Impact of high-speed rail stations on local development: A delphi survey. Built Environment, 38(1), 51-70. https://doi.org/10.2148/ benv.38.1.51

Loukaitou-Sideris, A., Higgins, H., \& Cuff, D. (2013). HSR development: Planning for high speed rail in Southern California communities. Los Angeles: UCLA Lewis Center and CityLab.

Loukaitou-Sideris, A., Peters, D., Colton, P., \& Eidlin, E. (2017). A comparative analysis of high-speed rail station development into destination and multi-use facilities: The case of San Jose Diridon. San Jose, CA: Mineta Transportation Institute Publications.

Lynch, K. (1960). The image of the city. Cambridge, MA: MIT Press.

Majoor, S., \& Schuiling, D. (2008). New key projects for station redevelopment in the Netherlands. Railway development: Impacts on urban dynamics (pp. 101-123). Heidelberg: Physica-Verlag HD. https://doi.org/10.1007/978-3-7908-1972-4_6

Metzger, J. (2014). The subject of place: Staying with the trouble. In Emergent urbanism: Urban planning \& design in times of structural and systemic change (pp. 91-100). Farnham, UK: Ashgate.

Monzón, A., Hernández, S., \& Di Ciommo, F. (2016). Efficient urban interchanges: The city-HUB model. Transportation Research Procedia, 14, 1124-1133. https://doi.org/10.1016/j.trpro.2016.05.183

Mota, C., \& López, M. A. (2014). Urban renovation through the implementation of a high-speed railway station. 20th International Conference on Urban Transport and the Environment, 138, 641-651. https://doi.org/10.2495/UT140531 
Muleya, N., \& Campbell, M. (2020). A multisensory approach to measure public space quality in the city of Bulawayo, Zimbabwe. Town and Regional Planning, 76, 56-71. https://doi.org/10.18820/24150495/trp76i1.5

Murgaš, F., \& Klobučník, M. (2016). Municipalities and regions as good places to live: Index of quality of life in the Czech Republic. Applied Research in Quality of Life, 11(2), 553-570. https://doi. org/10.1007/s11482-014-9381-8

Nag, D., Bs, M., Goswami, A., \& Bharule, S. (2019). Framework for public transport integration at railway stations and its implications for quality of life. SSRN Electronic Journal. https://doi.org/10.2139/ ssrn. 3551888

Najafi, M., \& Shariff, M. K. B. M. (2011). The concept of place and sense of place in architectural studies. International Journal of Human and Social Sciences, 6(3), 187-193.

Nuworsoo, C. K., \& Deakin, E. (2009). Transforming high-speed rail stations to major activity hubs: Lessons for California. Paper presented at the 88th Annual Meeting of the Transportation Research Board, Washington, DC.

Olaru, D., Moncrieff, S., McCarney, G., Sun, Y., Reed, T., Pattison, C., ... Biermann, S. (2019). Place vs. node transit: Planning policies revisited. Sustainability, 11(2), 477. https://doi.org/10.3390/ su11020477

Peek, G.-J., Bertolini, L., \& De Jonge, H. (2006). Gaining insight in the development potential of station areas: A decade of node-place modelling in The Netherlands. Planning Practice and Research, 21(4), 443-462. https://doi.org/10.1080/02697450701296247

Peek, G.-J., \& Louw, E. (2008). A multidisciplinary approach of railway station development: A case study of 's-Hertogenbosch. Railway development. Heidelberg: Physica-Verlag HD. https://doi. org/10.1007/978-3-7908-1972-4_7

Peek, G. J., \& Van Hagen, M. (2002). Creating synergy in and around stations: Three strategies for adding value. Transportation Research Record, 1793, 1-6. https://doi.org/10.3141/1793-01

Peters, D. (2009). The renaissance of inner-city rail station areas as a key element in the contemporary dynamics of urban restructuring. Critical Planning, 16, 163-185.

Peters, D., \& Novy, J. (2012). Train station area development mega-projects in Europe: Toward a typology. Built Environment, 38, 12-30. https://doi.org/10.2148/benv.38.1.12

Pugalis, L. (2009). The culture and economics of urban public space design: Public and professional perceptions. Urban Design International, 14(4), 215-230.

Rapoport, A. (1982). The meaning of the built environment. Beverly Hills: CA: Sage Publications, Inc.

Reusser, D. E., Loukopoulos, P., Stauffacher, M., \& Scholz, R. W. (2008). Classifying railway stations for sustainable transitions - Balancing node and place functions. Journal of Transport Geography, 16(3), 191-202. https://doi.org/10.1016/j.jtrangeo.2007.05.004

Rodríguez, D. A., \& Kang, C. (2020). A typology of the built environment around rail stops in the global transit-oriented city of Seoul, Korea. Cities, 100(November 2019), 102663. https://doi. org/10.1016/j.cities.2020.102663

Rond, J. (2011). Added value of railway station areas explored. Delft: Delft University of Technology.

Stevens, M. (2015). Hybrid infrastructures -Transit spaces as meta urban environments. International Journal of Contemporary Architecture, The New ARCH, 2(3), 1-10. https://doi.org/10.14621/tna.20150401

Tonkiss, F. (2009). Space, the city and social theory. International Journal of Urban and Regional Research, 33(3), 880-881. https://doi.org/10.1111/j.1468-2427.2009.00919_9.x

Trip, J. J. (2006). What makes a city? Planning for 'quality of place.' The case of high-speed train station area redevelopment. Delft: IOS Press, under imprint Delft University Press.

Trip, J. J. (2007). Assessing quality of place: A comparative analysis of Amsterdam and Rotterdam. Journal of Urban Affairs, 29(5), 501-517. https://doi.org/10.1111/j.1467-9906.2007.00362.x 
Trip, J. J. (2008a). Urban quality in high-speed train station area redevelopment: The cases of Amsterdam Zuidas and Rotterdam Central. Planning Practice and Research, 23(3), 383-401. https://doi. org/10.1080/02697450802423633

Trip, J. J. (2008b). What makes a city: Urban quality in Euralille, Amsterdam South Axis and Rotterdam Central. Railway Development: Impacts on Urban Dynamics (pp. 79-99). Heidelberg: PhysicaVerlag HD. https://doi.org/10.1007/978-3-7908-1972-4_5

UIC. (2018). High-speed railway: Fast track to sustainable mobility. https://doi.org/10.1007/978-3-64236051-0_6

Van Den Berg, L., \& Pol, P. M. J. (1998). The urban implications of the developing European highspeed-train network. Environment and Planning C: Government and Policy, 16(4), 483-497. https:// doi.org/10.1068/c160483

Vreeker, R. (2008). Multicriteria analysis of a high-speed railway station area development project. Railway Development: Impacts on Urban Dynamics. New York: Springer. https://doi.org/10.1007/9783-7908-1972-4_9

Wang, X. (2014). Shaping vibrant urban places in Chinese inner-city station areas: A case study of Beijing west station area. Architectural Research through to Practice: 48th International Conference of the Architectural Science Association, 2014, 671-682.

Wegener, M., \& Fuerst, F. (2004). Land-use transport interaction: State of the art. SSRN Electronic Journal. https://doi.org/10.2139/ssrn.1434678

Willigers, J., \& Van Wee, B. (2011). High-speed rail and office location choices. A stated choice experiment for the Netherlands. Journal of Transport Geography, 19(4), 745-754. https://doi.org/10.1016/j. jtrangeo.2010.09.002

Yin, M., Bertolini, L., \& Duan, J. (2015). The effects of the high-speed railway on urban development: International experience and potential implications for China. Progress in Planning, 98, 1-52. https://doi.org/10.1016/j.progress.2013.11.001

Zacharias, J., Zhang, T., \& Nakajima, N. (2011). Tokyo station city: The railway station as urban place. Urban Design International, 16(4), 242-251. https://doi.org/10.1057/udi.2011.15

Zemp, S. (2011). Sustainable positioning of railway stations systematic analysis for knowledge integration. Doctoral dissertation, ETH Zürich, Zürich. https://doi.org/10.3929/ethz-a-010782581 